\title{
Raising Awareness of Collocation in ESL/EFL
}

\section{Classrooms}

\author{
Parisa Farrokh \\ English Translation Department, Lahijan Branch, Islamic Azad University, Lahijan, Iran \\ E-mail: p_farrokh@yahoo.com
}

Received: April 9, 2012

Accepted: May 10, 2012

Published: August 1, 2012

doi:10.5296/jse.v2i3.1615

URL: http://dx.doi.org/10.5296/jse.v2i3.1615

\begin{abstract}
One of the most problematic areas for foreign language learning is collocation. It is often seen as arbitrary and overwhelming, a seemingly insurmountable obstacle to the attainment of native like fluency. The aim of this study is to increase awareness of the importance of teaching collocations in ESL/EFL classrooms in order for learners to acquire accurate and native-like competence. This paper is divided into four main sections. The first section discusses the definitions and categorizations of collocation from different scholars' perspectives as well as the distinction between collocation and other combinations of words. In the second section, the main sources of collocational errors will be clarified. The third section deals with the importance of collocations in ESL/EFL classrooms. In the fourth section different methodologies and materials for teaching collocations to ESL/ EFL learners will be suggested, as well as the implications of the lexical approach will be analyzed.
\end{abstract}

Keywords: Collocation, Categorization of collocation, Combinations of words, Collocational errors, Teaching collocations, Materials, The lexical approach 


\section{Introduction}

Collocations have been recognized as one of the ways that differentiate native speakers and second language learners. If a non-native speaker wants to help someone, she/he will say, "Can I help you?" whereas a native speaker will say, "Can I give you a hand?" (Salkauskiene, 2002).

English is full of collocations, recurrent combinations of words that co-occur more often than expected by chance. Why do we say 'last year' and not 'last hour'? And why do we go somewhere 'by car' or 'by train' but 'on foot'? The reason is 'collocation'. " Knowing the meaning of a word not only requires knowing its dictionary definition; one must also know the type of words with which it is often associated. Collocations, either fixed or more flexible, are the result of many years of habitual use by fluent speakers of the English" (Prodromou, 2004). It is believed that automation of collocations helps native speakers to express themselves fluently since it provides 'chunks' of English that are ready to use. Second and foreign language learners, however, because of lacking this automation, may make non-native errors when producing utterances. In order to achieve native-like competence and fluency, second and foreign language learners need to be aware that an important part of language acquisition is the ability to comprehend and produce collocations as unanalyzed chunks. Both learners and teachers of the English realize how complicated the area of collocation is. Lewis (2000) encourages teachers to raise students' awareness of collocations and to initiate their own action research to make sure the changes they make are of benefit to students. The purpose of this study is to investigate the different views regarding definition and classification of collocations, the importance of teaching collocation, the main sources of collocational errors and to suggest some methodologies and materials for teaching collocation in ESL/EFL classrooms.

\section{Literature Review}

The word collocation is a relatively new addition to the lexicon of English but defining collocation is a challenge since the term collocation has been a common concern among linguists, lexicographers and language pedagogues recently. However, it is not possible to discuss all of these perspectives in this essay. Therefore the researcher mentions some basic and general views regarding collocation in this section.

Collocation, originated from the field of lexicon studies, is a term defined and understood in many different ways (Bahns, 1993). Generally, there were two different sides of assertions about this term. One of them argued that collocation was related to meaning; the other argued that collocation was not a semantic relation between words.

For the assertion that collocation was concerning meaning, Firth has been regarded as the one responsible for bringing the term into prominence in the field of lexicon study (Carter \&McCarthy, 1988; Hill, 2000). In Firth's view, the meaning of a word should be known by the company it keeps.In other words, collocation is the meaning of a word and its relationship with other words (ibid). Such a notion about collocation is often applied to the subsequent researches related to collocation. 
McIntosh (1961) took Firth's viewpoint into further discussion. He added the notion of ranges, which meant, as Palmer (1976) defined, that a word might be used with a whole set of words that had some semantic features in common. An example of a range was the list of nouns, such as metal, iron, and lava, which might be qualified by the adjective molten. In McIntosh's opinion, words have only a certain tolerance of compatibility. Such knowledge of ranges helps to distinguish the acceptable collocations from unacceptable ones. (ibid). Similar to McIntosh (1961) and Palmer (1976), Bolinger and Sears (1981) also mentioned that the ranges and variety of collocations are enormous. They regarded collocation as "a kind of habitual association of words" and asserted that collocations resulted from native speakers' experiences of the expressions, repeated again and again in certain given circumstances. Therefore, depending on the context, the collocations, like good chance, high probability, and strong likelihood, might be considered acceptable, but the collocations like strong chance, good probability, and high likelihood, unacceptable. Based on Lewis' idea, "collocations are those combinations of words which occur naturally with greater than random frequency. Collocations co-occur, but not all words which co-occur, are collocations" (Lewis, 1997, p.44).Collocation also has been defined as a habitual association of words that co-occur with mutual expectancy. In other words, the collocations, like rancid butter, great probability and drug addict are words or phrases which are arbitrary (Nattinger \& DeCarrico,1992,p.56).

Sinclair (1966), in a volume of papers in memory of Firth, showed an interest in generating lexical sets by the use of collocation. For Sinclair, grammar and lexis are two different aspects. Grammar can be described by structures (syntagms) and systems (paradigms), while the second one is lexical items collocating with one another-collocations and sets respectively. According to Sinclair, collocation refers to as the co-occurrence of two words, but this co-occurrence is not indicative of two words occurring as a small fixed grammatical set. Instead, it has two important features. First, there may be several or many words between the two relevant items or the two relevant items may even occur over sentence boundaries. Second, collocation is independent of grammatical types. In other words, collocation is not analyzed by grammatical structures. The examples "he argued strongly," "the strength of his argument," "his argument was strengthened" illustrate a constant relationship between the two words (Sinclair, 1966, p.42). On the other hand, however, some researchers held different views from the above scholars' opinions. For example, McCarthy considered the notion of collocation as a kind of cohesive device. He claimed that collocation refers to the probability that lexical items will co-occur, and is not a semantic relation between words. (McCarthy, 1991, p. 65).Such opinion suggests that collocation serves other function besides meaning in the sentences. Another instance was Aghbar's (1990) proclamation. He proposed that the notion of collocation is not raised creatively for the first time; in fact, people have a memory of having heard or seen these constructions before and use them as such. Moreover, Halliday and Hasan (1976 cited in AL-Zahrani, 1998) defined collocations from the aspect of discourse. They defined collocations as "cohesive effect of pairs of words", such as flame...candle, king...crown and hair...comb (AL-Zahrani, 1998, p.19). They proposed that these patterns would generate a cohesive force if they occur in an adjacent sentence (ibid).Regarding collocations, however, there is a general definition: "collocations are loosely fixed, arbitrary recurrent word combinations and the meaning of the whole do reflect the 
meaning of the parts. Pure chance, to commit murder, close attention, and keen competition share the features of this category" (Benson et al., 1986b, p.23). They have also categorized collocations into two categories: lexical and grammatical collocations which will be discussed in the following.

\subsection{Collocation and Other Combinations of Words}

Words can be combined in numerous ways to form meaningful groups if those words are not restricted. That is what makes it hard to clarify the notion of collocation. Among these possible combinations of words, some are fixed and others are more loose. In order to attain a clearer understanding of collocation, it is necessary to draw a distinction among collocations, idioms, and other kinds of word combinations (Bahns, 1993; Wang, 2001; Wu, 1996), though these combinations are quite similar to one another, even, in a sense, belonging to the category of collocations(ibid). Wood (1981) adopted both semantic and syntactic criteria for distinguishing collocations from idioms, colligations, and free combinations. In Wood's point of view, an idiom is fully non-compositional and non-productive, while a free combination is fully compositional and productive. "Collocation is the way one word co-occurs with another word, colligation is the way one word regularly co-occurs with a particular grammatical pattern; so for example some verbs typically occur with a particular tense, or a noun might typically appear preceded by a personal pronoun, rather than an article, such as "pass my/your driving test, It's my/your/our responsibility to..., but I'll take the responsibility for" and etc (Wood, 1981, p.87).

Based on Howarth's model, there are four categories of word combinations:

(a) Free combinations: The meaning of a free combination is interpreted from the literal meaning of individual elements, such as drink tea.

(b) Restricted collocations: A restricted collocation is more limited in the selection of compositional elements and usually has one component used in a specialized context, such as perform a task.

(c) Figurative idioms: A figurative idiom has a metaphorical meaning as a whole that can somehow tell it's literal interpretation, such as do a U-turn.

(d) Pure idioms: A pure idiom is a single unit whose meaning is totally unpredictable from the meaning of it's components, such as blow the gaff.

Besides, Benson et al. (1986b) distinguished collocations from other combinations of words such as compounds, idioms, transitional combinations (transitional collocations), and free combinations. The following is the summary of the five types of word combinations, listed from the most fixed combination to the freest one.

1. Compounds: The most fixed word combinations, are completely frozen, and no variations at all are possible. The instances of nominal compounds are: floppy disk and aptitude test, and an illustration of compound verb (or phrasal verb) is break through. 
2. Idioms: Idioms refer to relatively frozen expressions whose meanings do not reflect the meanings of their component parts. The illustrations of idioms are: to kill two birds with one stone, to kick the bucket, to spill the beans, and so on.

3. Transitional combinations: The combinations whose meanings are close to their component parts, regarded as more frozen and less variable than collocations. Instances of such are: for old time's sake, the facts of life, to be in a tight spot, and the like.

4. Collocations: They are loosely fixed, arbitrary recurrent word combinations and the meaning of the whole do reflect the meaning of the parts. Pure chance, to commit murder, close attention, and keen competition share the features of this category.

5. Free combinations: Free combinations are taken as the least cohesive of all combinations. Their components are the freest in regard to being combined with other lexical items.

The typical combinations of this sort are: to recall an adventure (an event, an accident) and to analyze (report, investigate) a murder.

Echoing what Benson et al. (1986b) attested, Bahns (1993) also admitted that, different from idioms, the main characteristics of collocations are that their meanings reflect the meaning of their constituent parts, and that, in comparison with free combination, they are used frequently, spring to mind readily, and are psychologically salient. In other words, "there are transitional areas between free combinations and collocations, and between collocations and idioms". (Cruse, 1986, p. 41).

\subsection{The Categorization of Collocations}

Hsueh,(2000) claims when it comes to the classification of collocations, Benson et al.'s (1986a) has been second to none so far (Liu, 1999a, Tsai, 1996). Many collocational researches (Bahns, 1993; Chang, 1997; Liu, 1999a, 1999b, 2000a; Wang, 2001) were conducted by using what Benson et al. advocated about collocations. According to Benson et al., collocation can be sorted systematically into two major groups-lexical collocations and grammatical collocations. A lexical collocation could be made up of nouns, adjectives, verbs, or adverbs, like "warmest regards", "strictly accurate", and etc. There are seven types of lexical collocations, labeled from a to $\mathbf{g}$, whose structures and examples are given below.

\section{Lexical Collocations Adopted from Benson et al. (1986a)}

a. verb (donating creation or activation)+ noun (pronoun or prep. phrase)

compose music; make an impression;

b. verb (meaning eradication or nullification)+ noun

revoke a license; demolish a house

c. adjective + noun

strong tea; a rough estimate

d. noun + verb 
bees buzz; bombs explode

e. noun1 of noun2

a pack of dogs; a herd of buffalo

a herd of buffalo

f. adjective + adverb/ adverb + adjective

sound asleep; hopelessly addicted

g. verb + adverb

anchor firmly; argue heatedly

On the other hand, a grammatical collocation is made up of a dominant word, such as a noun, an adjective, or a verb, and a preposition or grammatical structure like an infinitive or a clause. Benson et al. (1986a) further categorized the grammatical collocations into eight small groups, marked as G1 to G8, among which, G8 collocations contained nineteen English verb patterns. To make the types clear, the researcher of the present study has listed the structures and examples of grammatical collocations here.

\section{Grammatical Collocations Adopted from Benson et al. (1986a)}

G1 noun + preposition;

$\mathrm{G} 2$ noun + to inf.

$\mathrm{G} 3$ noun + that clause

G4 preposition + noun;

G5 adjective + preposition

G6 predicate adjective +to inf.

$\mathrm{G} 7$ adjective + that clause

G8There are 19 patterns in G8:

svo to o (or) svoo

brother a book.

Svo to o

svo for o (or) svoo

bought her husband a shirt.

sv prep. o (or) svo prep. O

Sv to inf.

sv inf.
Apathy toward

He was a fool to do it.

He took an oath that he would do his duty.

in advance, at anchor

They are afraid of him.

It was stupid for them to go.

She was afraid that she would fail the exam.

He sent a book to his brother. He sent his

They described the book to her.

She bought a shirt for her husband. She

He came by train. We invited them to the meeting.

They began to speak

He had better go. 
svV-ing

svo to inf.

svo inf.

svov-ing

SV possessive v-ing

$\mathrm{sv}(\mathrm{o})$ that-clause

svo to be c

Svoc

SVOo

sv(o)adverbial

sv(o) wh-word

s(it) vo to inf. (or) s(it) vo that-clause
They enjoy watching television.

She asks me to come.

She heard them leave.

I caught them stealing apples.

Please excuse my waking you so early.

They admitted that they were wrong.

We consider her to be very capable.

She dyed her hair red.

We bet her ten pounds.

He carried himself well.

He wants what I want.

decision. It surprised me that our offer was rejected.

It surprised me to learn of her svc (adjective or noun)

She was enthusiastic. The flowers smell nice.

Sinclair (1991) divided collocation into two kinds-downward collocation and upward collocation. Different from Benson et al., Sinclair made use of two terms to classify collocations. One was the term "node," which was employed to stand for the word studied; the other was the term "collocate," used to represent any word occurring in the specified environment of a node. Based on Sinclair's claim, when A is" node" and B is "collocate"-collocation of A with a less frequent word B, it is called downward collocation, which contribute to a semantic analysis of a word. The examples of this type are "advantage over", "afraid of", "attitude toward", and etc. In contrast, when B is "node" and A is "collocate," it is called upward collocation. The examples of this type are "on purpose", "by accident", "with caution", etc. In this kind of collocation, "the words tend to be the elements of grammatical frames, or superordinates"(Sinclair,1991,p.116).

Similar to Benson et al. (1986a), Lewis (2000) listed different types of collocations.More types beyond Benson et al.'s classification are seen in his list. The researcher of the current study has rearranged them from the collocations related to nouns (from 1 to 8 ) to other types of collocations.

\section{The classification of collocations Adopted from Lewis (2000)}

1. adjective + noun: a difficult decision

2. verb + noun: submit a report 
3. noun + noun: radio station

4. verb + adjective + noun: revise the original plan

5. compound noun: fire escape

6. binomial: backwards and forwards

7. trinomial: hook, line and sinker

8. noun + verb: the fog closed in

9. verb + adverb: examine thoroughly

10. adverb + adjective: extremely inconvenient

11. discourse marker: To put it another way

12. multi-word prepositional phrase a few years ago

13. phrasal verb: turn in

14. adjective + preposition: aware of....

15. fixed phrase: On the other hand....

16. incomplete fixed phrase: A sort of....

17. fixed expression: Not half!

18. semi-fixed expression: See you later/tomorrow/on Monday.

19. part of a proverb: Too many cooks....

20. part of a quotation: To be or not to be.... (Lewis,2000,pp. 133-134)

Moreover, Lewis (1997) claims that generally, collocations can be classified into four groups: strong, weak, frequent, and infrequent. The distinction between strong and weak collocations is based on their fixedness and restriction, where as the distinction between frequent and infrequent ones is on the basis of their frequency of co-occurrence in a corpus. The strong collocations such as drink beer, drug addict, are recognized as tightly linked phrases which function like single word. While weak ones like a nice day or a good chance are combined with two common words, and each of which may occur with other words. Collocations, furthermore can be any combination of strong and frequent,strong and infrequent,weak and frequent or infrequent(ibid).

\section{The Causes of Collocational Errors}

Recent experimental studies have pointed out several factors that may influence ESL/EFL learners' performance in making correct collocations. The researchers discovered that the collocational errors resulted from analogy, overgeneralization, paraphrase, interlingual transfer, intralingual transfer, and shortage of collocational knowledge (Bahns \& Eldaw, 1993; Channel, 1981; Ellis, 1985; Farghal \& Obiedat, 1995; Liu, 1999a, 1999b, 2000b). For 
instance, Bahns and Eldaw (1993) proclaimed that many EFL students' collocation errors were caused by their L1 interference. Similar conclusion was made by Farghal and Obiedat (1995). They noted that the students who did not know a specific collocation tended to resort to the strategies such as synonym, paraphrasing, avoidance, and transfer. In addition, a series of studies conducted by Liu (1999a, 1999b, 2000b) revealed that the same strategies were used by EFL students in producing collocations, either acceptable or unacceptable, in their writings. To begin with, in the study of Chinese college freshmen's collocational competence, Liu (1999b) found that the EFL students had difficulties in producing acceptable collocation. He further concluded that the causes of producing unacceptable English collocations were mostly attributed to the lack of the concept of collocation and interlingual transfer. The results of the study have been summarized as follows:

1. Lack of collocational concept: Some students only understood the basic meaning of the word but did not know which word it would go with. Thus, they were not competent to produce any collocation.

2. Direct translation: Some students remembered only the Chinese translation of the word. Therefore, they relied on direct translation to produce collocations (e.g. *learn knowledge instead of gain knowledge or absorb knowledge).

3. Ignorance of rule restrictions: Some students did not know that some collocational restrictions were based wholly on the meaning of the word and range; others did not take grammar into consideration. As a result, they produced grammatically unacceptable collocations (e.g. *few knowledge instead of little knowledge).

4. Lack of knowledge of collocational properties: Many students did not understand the potential collocational properties of the words they knew. Take the word good for example. It could be assumed that most students knew the collocation a good boy, but few students generated the collocation a good knowledge.

Moreover, in Liu's (1999a) another analysis of collocational errors in EFL writings, with fourteen types of lexical and grammatical collocational errors studied in the students' compositions and examination papers, six sources of errors were found. Among them, a small number of errors resulted from word coinage and approximation belonged to communication strategies, while the majority of the errors were attributable to negative interlingual transfer. Four kinds of intralingual transfer-overgeneralization, ignorance of rule restrictions, false concepts hypothesized, and the use of synonyms belonged to cognitive strategies. The strategies concluded in Liu's (1999a) study were further accounted for as follows:

1. Negative interlingual transfer: Some collocational errors were caused by direct translation. Although phrases, like "*listen his advice" and "*wait your phone call," are understandable when they were translated back into Chinese, they were not acceptable English collocations. Being intransitive verbs, listen and wait could not be directly followed by a noun. The rule does not exist in Chinese, however.

2. Ignorance of rule restrictions: Analogy and failure to observe the restrictions of existing structures were at times the reasons why students produced unacceptable collocations. For 
example, "to *make Joyce surprise" was a false analogy of the construction verb + object + infinitive (e.g. "make Joyce surprised").

3. False concept hypothesized: Students had misconceptions about the verbs such as make, do, and take. Some students might think that these words were de-lexicalized verbs, thus they could be substituted for one another freely. For instance, students had used "*do plans" instead of "make plans."

4. Overgeneralization: Students used overgeneralization when the items did not carry any obvious contrast to them. It was the creation of one deviant structure in place of two regular structures on the basis of students' experience of the target language. For example, instead of using "am used to taking," students had used the collocation "*am used to take," which was a combination of "am used to something" and "used to take."

5. Use of synonyms: Students used "*receive other people's opinion" instead of "accept other people's opinions." It was taken as a straightforward application of the open choice principle.

6. Word coinage and approximation: Word coinage was a type of paraphrase employed to make up a new word in order to communicate the desired concept. The instance of the collocational errors resulted from word coinage was "to *see sun-up" (instead of "to see the sunrise"). On the other hand, approximation was another type of paraphrase. It was the use of an incorrect vocabulary item or structure, which shares enough semantic features in common with the desired item to satisfy the speakers. For example, the word middle in "*middle exam" was used to mean mid-term in "midterm exam." Furthermore, in another study on students' strategy used in producing lexical collocations, Liu (2000) mentioned seven types of strategies that EFL students might use in their writing, inclusive of observable actions and unobservable mental process. The followings are the seven types of strategies.

1. Retrieval: It means the students' ability to recall collocations from their memory. Without understanding the notion that language does not consist of words but of chunks, many students have no intention to store collocations in their memory. Consequently, they often fail in searching for the proper collocations they need when they communicate in either speaking or writing.

2. Literal translation: Students tend to transfer the thought word-for-word from L1 to L2 when not succeeding in finding stored collocations. They take the strategy of literal translation to produce either acceptable or unacceptable collocations.

3. Approximate translation: Approximate translation is a process of paraphrasing the thought from L1 to L2. Sometimes students rely on their intuition to create collocations of their own and choose approximate translation as another strategy other than literal translation.

4. Use of de-lexicalized verbs: Students are inclined to use de-lexicalized words (e.g. do, take, make, and keep) carelessly and substitute one for another casually in their writing. Owing to linguistic deficiencies, intermediate EFL students often consider de-lexicalized verbs as words that have little or no meaning outside the context of particular use. 
5. Use of synonyms: It is the using of synonyms that students solve L2 lexical problems when they encounter the collocations that they are not able to bring out. Nevertheless, more often, they produce erroneous collocations as a result of the insufficient collocational information of the synonyms they use.

6. Appeal to authority: When students are unable to find the right collocation to use, they would like to ask a native speaker or consult a dictionary for the answer. However, if their problems would be solved depended on what kind of dictionary they usually used and whether they could find the answer in a dictionary.

7. Appeal for assistance: Learners have a tendency to depend on others for guidance and instruction. Chances are that most of the time the poor writers are the ones seek advice from.

Regarding the negative effect of L1, the results of the study conducted by Koosha and Jafarpour (2006) also confirmed the influence of L1 on acquiring collocation of prepositions by Iranian EFL adult learners. Furthermore, Namvar et al.'s research also analyzed the collocations in the Iranian postgraduate students' writings and found that negative transfer is a common phenomenon among Iranian language learners. In other words, first language influence appears to have a strong effect on the learners' production of collocational errors.

\section{The Importance of Collocations in ESL/EFL Classrooms}

According to Benson et al.(1985),collocations are arbitrary and unpredictable" and that makes it difficult for non-native speaker to cope with them. Despite the arbitrary nature of collocations, it is recommended by many other researchers that teachers should motivate their students to learn collocations.

According to Cowie (1992), English collocation is important in receptive as well as productive language competence. Similar assertion was made by Carter and McCarthy (1988). In their opinion, English collocations are useful not only for English comprehension but for English production. They claimed that by memorizing collocational groups, students would have the idea about certain lexical restrictions. Most importantly, "collocations teach students expectations about which sorts of language can follow from what has preceded. Students will not have to go about reconstructing the language each time they want to say something but instead can use these collocations as pre-packaged building blocks" (Carter \& McCarthy,1988, p. 75).

Moreover, it can be said that "collocation has emerged as an important category of lexical patterning and it is fast becoming an established unit of description in language teaching courses and materials" (Woolard, 2000, p.28). Liu (2000a) also stated that the more often students are taught English collocations, the more correctly students can make use of collocations.

Such declaration was supported by Lin (2002), while investigating the effects of collocation instruction on students' English vocabulary developments. Lin (2002) found that students made progress in producing collocations after receiving collocation instruction. Here a review 
of three of the most common arguments stressing the importance of developing collocational knowledge of language learners is presented.

\subsection{Language Knowledge Requires Collocational Knowledge}

Collocations are everywhere. "Collocations are found in up to $70 \%$ of everything we say, hear, read, or write" (Hill, 2000,p.53).Collocation highlights the strong patterning that exists in language and shows that a word-by-word approach cannot satisfactorily account for meaning in a text. Nation writes that the strongest position is that language knowledge is collocational knowledge because the stored sequences of words are the bases of learning, knowledge and use (Nation, 2001,p. 321).

\subsection{Efficient Language Acquisition Requires Collocational Knowledge}

It is generally accepted that language is acquired faster and more efficiently when learned in 'chunks', such as set phrases or routines (Ellis, 2001, p.67). There is a substantial psycholinguistic evidence which supports this. Based on Schmitt's belief, "lexical phrases in language reflect the way the mind tends to 'chunk' language in order to make it easier to process"(Schmitt,2000,p.78). Aitchison states there are powerful and long-lasting links between words in the mind (Aitchison, 1987, p.79). In first language acquisition young children acquire language in chunks even it is claimed for producing collocational constructions, they could not have learned from their parents (Pinker, 2007, p.55). Gleason states that "working on the second language acquisition indicates that the second language learners begin not so much with generative systems as with chunks, prefabricated routines, or unopened packages'(Gleason, 1982, p.355). In a comparative study of L1 and L2 English speakers, Conklin and Schmitt (2008) found that what they term 'formulaic sequences' were read more quickly than non-formulaic sequences by both groups of participants, supporting the assertion that such chunks 'have a processing advantage over creatively generated language' (Conklin \& Schmitt,2008, p.72).

All of the above evidences appear to support the view that collocations are organized in the mind in some way to enable more efficient language processing, for both language reception and language production.

\subsection{Fluent Language Use Requires Collocational Knowledge}

A third reason cited supporting the teaching of collocation is that fluent and appropriate language use requires collocational knowledge. According to Pawley and Syder:

"Memorized clauses and clause-sequences form a high proportion of the fluent stretches of speech heard in everyday conversation ... Speakers show a high degree of fluency when describing familiar experiences or activities in familiar phrases ... We believe that memorized sentences and phrases are the normal building blocks of fluent spoken discourse". (Pawley \& Syder, 1983, p.208).

There have been several studies which support this position. Towell, Hawkins and Bazergui (1996) in a study of learners of French as a second language found that increased fluency resulted from learners storing memorized sequences. Sung (2003), in a study of international 
students in the USA, found a significant correlation between the knowledge of lexical collocations and the subjects' speaking proficiency as did Hsu and Chiu (2008) in a study of Taiwanese EFL learners. The three positions summarized stressing the importance of teaching collocation in ESL/EFL classrooms. Accepting that collocation should be taught to ESL/EFL learners, we need to consider how this might best be done.

\section{Suggestions for Teaching Collocations}

In this section I will discuss some approaches to teach collocation as well as selected examples of typical collocations. Since collocations, as they are defined in this paper, come in various forms, some learning activities are more suited to teach certain types of collocations than others.

\subsection{Deliberate Learning of New Collocates}

In one of the earliest studies recommending the explicit teaching of collocation, Channell (1981) found that learners fail to realize the potential of known words as they only use them in a limited number of collocations that they feel sure of. To overcome such limited use of collocations, Channell argued that it is essential to expose learners to a large variety of typical collocations whenever a word is first acquired. She recommended doing this, use examples, sentences or collocational grids such as this one: (Channell,1981,p. 120).

\begin{tabular}{|c|c|c|c|c|c|c|c|c|c|c|c|c|c|c|c|c|}
\hline & 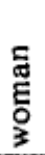 & $\stackrel{\text { I }}{\stackrel{\text { }}{ }}$ & 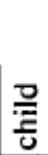 & ఫొ & 设 & 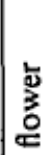 & 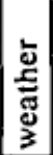 & 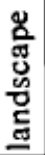 & .0 & 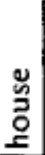 & 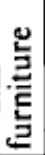 & : & 包 & $\begin{array}{l}\tilde{u} \\
\stackrel{\tilde{s}}{0}\end{array}$ & 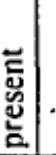 & $\frac{\mathscr{c}}{\stackrel{0}{0}}$ \\
\hline handsome & & + & & & & & & & & 7 & + & 4 & 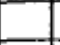 & + & + & \\
\hline pretty & + & & + & + & + & + & & + & + & + & & + & + & + & & \\
\hline charming & + & & + & & & & & & & + & & & & + & & + \\
\hline lovely & + & & + & + & + & + & + & + & $\begin{array}{lll}+ & & \\
\end{array}$ & + & + & + & + & +1 & + & + \\
\hline
\end{tabular}

Grids are espe) cially suited to presenting many adjective + noun and delexical verb + noun combinations. For example, grids can be used to demonstrate acceptable adjective + noun collocations, such as qualified physiotherapist, as well as unacceptable ones(ibid). However, Nesselhauf believes that grids are limited in their effectiveness as they only provide information on the form, not the usage of collocations. She argues that knowledge of all aspects of usage (for example, semantic prosody, pragmatics and stylistics) can only be learned in typical contexts (Nesselhauf, 2005,p. 269). However, as Carter points out, teachers sensitive to teaching vocabulary in context will not present the grids as immutable, but rather as the hypotheses which learners can test against further data(Carter,1998,p. 217). In light of this, it is important to remember the limitations of grids and to use them appropriately in conjunction with other learning activities.They are also suitable for developing learner awareness of the restrictions of delexical verb + noun combinations exemplified in get my tea, going on holiday and made him some tea and etc., after they had encountered them in a text (ibid). 


\subsection{The Corpus and Concordances}

Shin and Nation (2007), Fox (1998) and Willis (1998) suggest that it is important to use spoken language to decide which collocations to teach. Fox (1998) adds that the ten million words which are found in the spoken section of the British National Corpus (BNC) could be used as a source for the most common patterns of spoken collocations. One problem seems to be that language changes overtime and these collocations might significantly change within years which require frequent updating of the list. Fox also believes that words should be taught according to their absolute frequency. He adds that it is not the only criteria but it helps teachers to focus on the most important and common words. It is equally important to know the less frequent collocations so time will not be wasted on teaching them. Fox makes the assertion that teachers should give students strategies to cope with collocation, one of which is the use of concordances (Fox, 1998, p.80). Concordance is defined by Koosha and Jafarpour (2006) as "a method of analyzing language by studying structures and lexical patterns found in digital database". Concordances might help students to recognize the collocation in different contexts and consequently know how it is used by native speakers(ibid). According to Willis (1998), concordances help students to speak and write fluently and naturally especially these days when most students have access to the electronic database. He believes that this activity could be useful for raising awareness of delexical verb + noun collocations (get my tea) and phrasal verbs (put the light on).

\subsection{Dictionaries}

Another valuable source of data, especially for more proficient learners, is collocation dictionaries. Using dictionaries in the class, provide as well as independent learning strategy to further develop learners 'collocational knowledge. For example, "if learners have difficulty with the phrase She's made a fool of you, they could be asked to look at the entry for fool in a good English-English dictionary"(Fox,1998,p.82). The entry for fool in the Collins COBUILD Advanced Learner's English Dictionary (2003) provides the following information and examples:

"If you make a fool of someone, you make them seem silly by telling people about something stupid that they have done, or by tricking them. Your brother is making a fool of you... He'd been made a fool of". Learners gain several benefits from this type of information. They get some contextual information on the use of the expression which should assist their understanding of it as well as get to see the degree of restriction. In addition, this particular dictionary entry also has examples of other expressions using fool, such as more fool you, play the fool and act the fool, providing a further learning opportunity for the more advanced learner. However, to gain the maximum benefit from using dictionaries learners need a systematic way of recording the information they receive. If learners can be taught to use dictionaries effectively, they will be more able to independently explore collocation and thus develop their collocational knowledge outside the classroom(ibid).

\subsection{Collocations in Texts}

Teachers can utilize texts from newspapers or magazines as authentic materials. These could be used to identify the appropriate ways of combining words. The following extract from the Times newspaper illustrates this method: “The figures, coming after a surprise fall to 51.8 in 
November, suggest Britain's economy ended the year on a strong footing and will boost expectations that the country emerged from recession in the fourth quarter with positive GDP growth". Teachers can highlight some of adjectives like: surprise, strong, boost, positive. Students could identify the collocations in the text or use dictionaries to create other possible collocations (Fox,1998,p.85).

\subsection{Input Enhancement and Learning Collocations}

Khanchobani (2012) states that one of the ways of directing learners attention to formal aspects of language is visual input enhancement, which is an implicit and unobtrusive means to increase the perceptual salience of the target forms via a variety of typographical techniques such as underlining, bolding, highlighting, etc. According to her, many researchers have focused on the effects of visual input enhancement such as Alanen, 1995; Doughty, 1991; Shook, 1994; Williams, 1999; Gharaee, 2002. Since input enhancement, is the implicit and unobtrusive means to draw the learners attention to form contained in the written input, therefore, Input enhancement makes it possible to maintain the massage while the intended language features are focused.(ibid). Based on Rezvani's research (2011), the learners who received input enhancement treatment made significant gains with regard to the acquisition of grammatical collocations.

\subsection{Output Tasks and Learning Collocations}

In the 1980s, the word output was used to refer to the outcome, or product, of the language acquisition process.(Rezvani,2011). Output was synonymous with what the learner has learned. However, with the proposal of Swain's Output Hypothesis (1985, 1995, 2000, 2005), output has come to be deemed not merely as an end product of learning, but as an important factor to promote L2 learning. It has been noted that producing the target language provides learners with unique opportunities for a level of processing (i.e., syntactic processing) that may be needed for the development of target-like proficiency and higher accuracy.Swain claims that while learners attempt to produce the target language (vocally or silently), they may notice that they do not know how to say (or write) precisely the meaning they wish to convey (ibid). This, in turn, may prompt second language learners to recognize consciously some of their linguistic problems and bring their attention to what they need to solve their linguistic deficiency (ibid). The results of Rezvani's research (2011) revealed that output tasks lead to significant acquisition of grammatical collocations by Iranian EFL learners.

\subsection{Implications of the Lexical Approach for Teaching Collocations}

According to Channel (1981 cited in Lewis, 1997), most of students' errors are resulted from lacking of emphasis on vocabulary in syllabi. It is not surprising that most syllabi are organized to cover more grammar than vocabulary, which prevent students making the right choice when it comes to creating collocations. The lexical approach is based on perceiving a language as basically "holistic-organic" (Lewis, 1997, p.34). Lewis states that one major principle of the lexical approach is that "language consists of grammaticalized lexis, not lexicalized grammar" (ibid). In other words, language consists of chunks not individual words. Collocations are considered as a central linguistic idea of the lexical approach. There are two reasons provided 
by Lewis in teaching words with other partner-words rather than teaching individual vocabulary. Firstly, vocabularies do not normally occur as separate words in texts but they occur in relation with other words and this probably makes it difficult to teach the possible partners that a single word may take. Secondly, it is considered easier to teach the language as a whole and then break it down to its basic components rather than teaching individual words and asking learners to construct sentences (ibid).

\section{Conclusion}

This paper sketched the various facts of the quaint combinations of words, i.e. collocations. The differences between collocations and other combinations of words and also types of collocations were discussed. As a whole, it can be mentioned that there are three filters to define collocations: co-occurrence, semantic restriction and meaning transfer. Moreover, collocations fall mainly into two general groups: lexical and grammatical collocations. Recent research has indicated that the main sources of collocational errors are analogy, overgeneralization, paraphrase, interlingual transfer, intralingual transfer, shortage or lack of collocational knowledge and ignorance of rule restrictions. Individuals need to address the issue of collocation in order to become more successful in language learning. Moreover, it is widely acknowledged in the English Language Teaching (ELT) literature that students need to be introduced and encouraged to become aware of collocation in the early stages of learning. In other words, the importance of collocational knowledge to language learning is well established. It has a central role in efficient language acquisition and proficient language production. A language can neither be adequately understood nor fluently produced on a word-by-word or purely grammar-focused basis. Preparing the students to use collocations effectively and appropriately will contribute to efficient communication. Particularly, the teaching of collocations to ESL/EFL learners, who have limited structural and lexical knowledge, can be fruitful. In addition, based on this research, various approaches and materials need to be taken into account to teach collocations and to help to minimize the learners' errors of collocations such as using grids, corpus and concordances,dictionaries, authentic texts and also enhancing input and output tasks. Besides, the researcher proposes the using of lexical approach to teach collocation inESL/ EFL classrooms. To sum, a greater emphasis on collocation in language teaching and learning is needed if more learners of English are to truly 'find their feet' in the language.

\section{References}

Aghbar, A. A. (1990). Fixed Expressions in Written Texts: Implications for Assessing Writing Sophistication. (pp.33-44). Paper presented at a Meeting of the English Association of Pennsylvania State System Universities.

Aitchison, J. (1987). Words in the Mind. Oxford: Blackwell.

Al-Zahrani, M. S. (1998). Knowledge of English lexical collocations among male Saudi college students majoring in English at a Saudi university. Doctoral dissertation, Indiana University of Pennsylvania, Pennsylvania. 


\section{Macrothink}

Journal of Studies in Education

ISSN 2162-6952

2012, Vol. 2, No. 3

Bahns, J. (1993). Lexical collocations: A contrastive view. ELT Journal, 47(1), 56-63. http://dx.doi.org/10.1093/elt/47.1.56

Bahns, J., \& Eldaw, M. (1993). Should we teach EFL students collocation? System, 21(1), 104-114. http://dx.doi.org/10.1016/0346-251X(93)90010-E

Benson, M., Benson, E., \& Ilson, R. (1986a). The BBI combinatory dictionary of English: A guide to word combinations. (pp.i-v). Amsterdam: John Benjamins.

Benson, M., Benson, E., \& Ilson, R. (1986b). Lexicographic description of English. (p.24). Amsterdam/Philadelphia: Benjamins.

Benson, M., Benson, E., \& Ilson, R. (1985). The structure of the collocational dictionary. International Journal of Lexicography, 2, 1-14. http://dx.doi.org/10.1093/ij1/2.1.1

Bolinger, D., \& Sears, D. A. (1981). Aspects of language. (pp.87-88). New York: Harcourt Brace Jovanovich, Inc.

Carter, R. (1998). Vocabulary: Applied Linguistics Perspectives. London: Routledge. http://dx.doi.org/10.4324/9780203270110

Carter, R., \& McCarthy, M. (1988). Vocabulary and language teaching. (pp.68-75). New York: Longman.

Channell, J. (1981). 'Applying semantic theory to vocabulary teaching'. ELT Journal, 2, 115-122. http://dx.doi.org/10.1093/elt/XXXV.2.115

Conklin, K., \& Schmitt, N. (2008). 'Formulaic Sequences: Are They Processed More Quickly than Nonformulaic Language by Native and Nonnative Speakers?'. Applied Linguistics, 29/1, 72-89. http://dx.doi.org/10.1093/applin/amm022

Cowie, A. (1992). Multiword lexical units and communicative language teaching. Inp. Arnaud \& H. Bejoint (Eds.), Vocabulary and applied linguistics. (pp. 216-331). London: Macmillan Academic and Professional LTD.

Cruse, D. A. (1986). Lexical semantics. Cambridge: Cambridge University Press.

Ellis, N.C. (2001). Memory for language. In Robinson, P. (ed.). (2001). Cognition and Second Language Instruction. Cambridge: Cambridge University Press.

Ellis, R. (1985). Understanding second language acquisition. (p.47). Oxford: Oxford University Press.

Farghal, M., \& Obiedat, H. (1995). Collocations: A neglected variable in EFL. IRAL, 33(4), 315-333. http://dx.doi.org/10.1515/iral.1995.33.4.315

Fox, M. (1998). Teaching collocations: Further developments in the lexical approach. Hove: Language Teaching Publications. 
Gleason, J.B. (1982). 'Converging evidence for linguistic theory from the study of aphasia and child language'. In Obler, L.K. and Menn, L. (1982). Exceptional Language and Linguistics. New York: Academic Press.

Hill, J. (2000). Revising priorities: From grammatical failure to collocational success. InM. Lewis (Ed.), Teaching collocation: further developments in the lexical approach. (pp. 49-60). London: Language Teaching Publications.

Howarth, P. (1993). A phraseological approach to academic writing. In G. Blue (Ed.), Language learning and success: studying through English. (pp. 58-69). London:Macmillan.

Hsu, J.T., \& Chiu, C. (2008) 'Lexical Collocations and their Relation to Speaking Proficiencyhttp://www.word collocations/two tech.html.pdf.

Hsueh.S.C. (2008). A study on the relationship between collocations and English writing. http://www.grammatical collocation/ppb/3j.net.pdf.

Khanchobani, A. (2012).Input enhancement and EFL learners' collocation acquisition. International journal of Academic research, 4(1), 96-101. http://www.researchgate.net.

Koosha, M., \& Jafarpour, A.A.(2006). Data-driven Learning and Teaching collocation of prepositions: The Case of Iranian EFL Adult Learners. Asian EFL Journal,8/8, 23-32.

Lewis, M. (1997). Implementing the lexical approach. (pp.34-44). England: Language Teaching Publication.

Lewis, M. (2000). Language in the lexical approach. In M. Lewis (Ed.), Teaching collocation: further developments in the lexical approach. (pp. 133-134). London: Language Teaching Publications.

Lin, Y. P. (2002). The effects of collocation instruction on English vocabulary developments of senior high students in Taiwan. (pp.87-90). A Master's Thesis Submitted to English Department of kaohsiung. University.http://www.techingcollocation.ednknu.html.pdf.

Liu, C. P. (1999a). An analysis of collocational errors in EFL writings. The proceeding of the eighth International Symposium on English Teaching. (pp. 483-494). Taipei: The Crane Publishing Co. Ltd.

Liu, C. P. (1999b). A study of Chinese Culture university freshmen's collocational competence: "Knowledge" as an example. Hwa Kang Journal of English language \& literature, 5, 81-99.

Liu, C. P. (2000). A study of strategy use in producing lexical collocations. Selected papers from the tenth International Symposium on English Teaching. (pp. 481-492). Taipei: Crane.

Namvar, F., Mohd Nor, N.F., \& Ibrahim, N. (2012).Analysis of collocations in the Iranian postgraduate students' writings. The Southeast Asian Journal of English Language Studies, 18(1), 11 - 22. http://www.ukm.my/mbp/31/. 
Nation, I.S.P. (2001). Learning vocabulary in another language. Cambridge: Cambridge University Press.

Nattinger, J. R., \& DeCarrico, J. S. (1992). Lexical phrase and language teaching. Oxford:Oxford University Press.

Nesselhauf, N. (2005). Collocations in a Learner Corpus. Amsterdam: John Benjamin.

Pawley, A., \& Syder, F.H. (1983). 'Two puzzles for linguistic theory: Native like selection and native like fluency'. In Richards, J.C. and Schmidt, R.W. (eds.). (1983). Language and Communication. London: Longman.

Pinker, S. (2007). The Stuff of Thought. London: Penguin.

Prodromou, L. (2003). Collocation. Retrieved March 16th, 2005, from the Language Study section of the Macmillan Essential Dictionary Webzine, published by Macmillan Publishers, http://www.macmillandictionary.com/med-magazine/May2004/19-Language-Study-Collocati on-UK.htm.

Rezvani, E. (2011).The effect of output requirement on the acquisition of grammatical collocations by Iranian EFL learners. Journal of Language Teaching and Research, 2(3), 674-682. http://dx.doi.org/10.4304/j1tr.2.3

Salkauskiene, D. (2002). Review of the book Teaching Collocation: Further Developments in the Lexical Approach, [Electronic version]. The Journal of Communication and Education: Language Magazine, 4,7.

Schmitt, N. (2000). Vocabulary in Language Teaching. Cambridge: Cambridge University Press.

Shin, D., \& Nation, P. (2008). 'Beyond single words: the most frequent collocations in spoken English'. ELT Journal, 62, 339-348. http://dx.doi.org/10.1093/elt/ccm091

Sinclair, J. M. (1991). Corpus, concordence, collocation. Oxford University Press.

Sinclair, J.M. (1966) 'Beginning the study of lexis'. In Bazell, C.E., Catford, J.C., Halliday, M.A.K. and Robins, R.H. (eds.) (1966). In Memory of J.R.Firth. London:Longman.

Sung, J. (2003). English lexical collocations and their relation to spoken fluency of adult non-native speakers.(pp.66-67). Ph.D thesis, Indiana University of Pennsylvania.http://www.lexical.inup/pdf.

Towell, R., Hawkins, R., \& Bazergui, N. (1996). The development of fluency in advanced learners of French. Applied Linguistics, 17, 84-119. http://dx.doi.org/10.1093/applin/17.1.84

Tsai, A.S.(1995).An empirical study of collocation teaching. Proceedings of the seventeenth conference on English Teaching and Learning in the Republic of China (pp. 165-178). Taipei: Crane. 


\section{Macrothink}

Wang, C. S. (2001). A study of the English collocational competence of English majors in Taiwan.(p.98). A Master's Thesis Submitted to English Department of Fu Jen Catholic University.http://www.collocation.fujcu.html.

Willis,Y.(1998).Teaching collocations for productive vocabulary development. (pp.25-33). Paper presented at the Annual Meeting of the Teachers of English to Speakers of Other Languages. NewYork, NY. (ERIC Document Reproduction Service No. ED457690).

Wood, M. (1981). A definition of idiom. Manchester, England: Center for Computational Linguistics, University of Manchester.

Woolard, G. (2000). Collocation-encouraging learner independence. In M. Lewis (Ed.), Teaching collocation: further developments in the lexical approach. (pp. 28-46).London: Language Teaching Publications.

Wu, W. S. (1996). Lexical collocations: One way to make passive vocabulary active. (pp. 461-480). Papers from the eleventh conference on English Teaching and Learning in the Republic of China. Taipei: The Crane Publishing Co. Ltd. 